\title{
The Political Slogan in Communist Czechoslovakia (1948-89)
}

\section{Tom Dickins}

Next year will witness four momentous anniversaries in Czechoslovak history: a century since the foundation of the First Republic (October 1918), eighty years since the Munich Agreement (September 1938), seventy years since the Communist takeover (February 1948) and fifty years since the Soviet-led military intervention (August 1968). While the establishment of the Czechoslovak state is now usually regarded as a high point in Czech, although not Slovak history, the Communist regime is generally dismissed as an aberration. ${ }^{1}$ Yet, paradoxically, the latter derived much of its support and legitimacy from disenchantment with the perceived failings of the 'bourgeois' inter-war republic. In the immediate post-war years, Communist propaganda was effective in attributing the economic hardships of the 1930s, the annexation of the Sudetenland and the subsequent German occupation of the rump Czech-speaking lands, to the shortcomings of capitalism and the perfidy of Czechoslovakia's Western allies. It further successfully exploited the role of the Red Army as the 'liberator' of the country, and promoted the image of the Soviet Union as the ideological exemplar. Notwithstanding the excesses of the early Communist period, pro-socialist sentiment and a sense of gratitude to the Soviet people for their role in 1945 persisted into the 1960s. The violent suppression of the Prague Spring dramatically undermined the credibility of Communist rule and of the USSR, but it did not completely destroy people's belief in the basic tenets of socialism (as evidenced by opinion surveys cited later). ${ }^{2}$

It is against the backdrop of the aforementioned shifting realities and changing perceptions that the theme of the current article - the political slogan - is set. The slogan contributed to a broader propaganda campaign, which reinforced carefully selected interpretations of the past, and rendered alternative readings of history more problematic. Although the impact of the myth-making inevitably diminished with time, it retained at least a degree of legitimacy throughout the entire period of Communist rule. Jindřich Kabát, whose work is informed by psychological theory, argues that, while humans cannot be constantly manipulated forever, 'some traces of the past will continue to influence our attitudes, without us realizing why ${ }^{9}$ In terms of R.C. Atkinson and R.M. Shiffrin's multi-store model of memory, the reiteration of the same themes, albeit ones heavily prescribed and manipulated by official explications, contributed to the creation of long-term (sometimes distorted or false) memories ${ }^{4}$ The slogan derived much of its connotative sense, which increasingly exceeded in importance its denotative sense, from this interdiscursive, impressionistic dimension. The ritualistic aspect of propaganda promoted a feeling of continuity, which helped both to normalize the world in which people found themselves, and to obfuscate the disjuncture between the official word and their everyday lives. As David I. Kertzer, who employs anthropological and historical perspectives, has observed: 'Ritual helps give meaning to our world in part by linking the present to the past and the present to the future'.

There are several reasons to reconsider this topic now, in the light of the attention focused on Czechoslovakia in the coming year of anniversaries. First, there have been no major studies of the functions and features of the Czech and Slovak political slogan. ${ }^{6}$ Its significance is implicitly acknowledged by the extensive range of examples cited in various publications and on websites, but none seeks to place it in its broader ideological and historical context. ${ }^{7}$ Jiří Pruša's comprehensive lexicon of 'socialist speak' attempts to categorize key phrases (including some slogans), but the twelve categories that he proposes relate more to people's lived experience than to the role of propaganda. ${ }^{8}$ Petr Fidelius's seminal work on language under Communism similarly includes in-depth analysis of some of the lexical items and expressions which featured in slogans, but he does not look at the slogan as a discrete entity. ${ }^{9}$ Second, the slogan was at the very heart of Communist propaganda. The authority vested in it by the Central Committee rendered it unchallengeable, and the identification of key themes constituted a kind of checklist of the regime's priorities. Third, the slogan was the most gnomic, distilled and perspicuous manifestation of Party ideology. Its essence could be largely understood without formal education or reference to alternative sources of information. Fourth, its ubiquity made it inescapable even to those whose lifestyle or personal circumstances limited their 
contact with other forms of political discourse. In one way or another, all Czechs and Slovaks were influenced not just by the content of slogans, but also by their omnipresence. Fifth, the slogan is increasingly misrepresented as temporally fixed and conceptually static. While it is true that the slogans were largely non-reactive and 'samey', and many were merely copies of the Russian original, they were not all identical either to each other or to their Soviet equivalents. My research suggests that the 'perennial' slogans (or evergreeny, as they are sometimes called in Czech) accounted for fewer than half of all the different 'types' of slogan, and that the others embraced a diverse range of themes. Oldřich Tůma, amongst others, is rightly critical of this growing trend to treat the erstwhile regime as an 'immobile monolith', and to overstate its immutability. ${ }^{10}$ Sixth, there is a tendency nowadays to dismiss the slogan, along with other forms of Communist propaganda, as meaningless and even counter-productive. That it was crude and hackneyed is beyond dispute, but it nonetheless performed a key ideological and psychological function, which helped to maintain the Party's grip on power.

This study adopts an interdisciplinary approach which combines linguistic, political and historical analysis, with selected reference to psychological, folkloristic and anthropological research. In terms of language analysis, the slogan invites both quantitative and qualitative methods of investigation. The slogan is better suited to positivist interpretation than more periphrastic political narrative, although it does not allow for the same degree of interpretivism as more complex forms of expression. It lends itself especially well to corpus-assisted discourse analysis, which sheds light both on the frequency of lexical usage, and on synchronic and diachronic variation. With some notable exceptions, such as Fidelius's work, and Alex Röhrich's qualitative analysis of the Party daily Rudé právo from 1953 and 1975, there have been few corpus-informed studies of Communist rhetoric. ${ }^{11}$ Moreover, virtually no attention has been paid to the development of the political slogan in Czechoslovakia over time. The only large-scale corpus of the Czech language under Communism, 'Totalita' (Totalitarianism), comprising fifteen million words, which is based on texts from Rudé právo from 1952, 1969 and 1977, does not draw on other sources in which slogans were well represented (such as posters, banners and chants). ${ }^{12}$ In respect of political and historical analysis, the principal framework adopted here is that of Alexei Yurchak, which applies Bakhtin's concept of hierarchically superior texts, and has been developed in the Czechoslovak context by Michal Pullmann. ${ }^{13}$ Extensive reference is also made to a variety of general historical and political sources, and to more specialist studies of Communist propaganda, including Philip Wander's description of ideological criticism and dogmatism, and Jaroslav Pažout's edited volume on the 'information war'. ${ }^{14}$ Particular importance is accorded to the relationship with the USSR, as this was the key determinant of the direction of Czechoslovak politics. ${ }^{15}$

\section{The Concept of the 'Political Slogan'}

'Political' is interpreted here in a broad sense as reflecting the values and policies of a government or party (in this case, the Communist Party of Czechoslovakia [KSČ]]). It often refers to economic matters, but it can relate more generally to public affairs, or to, say, social, cultural, religious or defence policy. The semantic and stylistic parameters of the term 'slogan' are more difficult to delineate. The Oxford English Dictionary defines it as 'a motto associated with a political party or movement or other group', while 'motto' is defined as 'a short sentence or phrase chosen as encapsulating the beliefs or ideas of an [...] institution'. ${ }^{16}$ The standard Czech term for slogan, 'heslo', is defined in the most authoritative (Communist-period) Czech dictionary, as 'the main thought, the essence; a verbal expression of that thought; a maxim', while the loanword 'slogan' is defined as 'a constantly repeated thought, of its time or in vogue $[\ldots]$ '. ${ }^{17}$

There is no satisfactory single definition of the concept of the 'political slogan', but it amounts to a pithy, self-contained and iconic articulation of an idea, which is inextricably linked to a set of defining principles and aspirations. It is usually an expression of faith, a reminder, an exhortation or a warning, and is generally devoid of humour, paradox or any other more complex or creative narrative perspective. It can have a strong pedagogical or didactic dimension, which seeks to modulate people's attitudes and behaviour. The solutions and explanations that it proposes are often simplistic and bombastic, and appeal to popular sentiment or prejudice. On the one hand, the political slogan may not appear to lend itself ideally to more detailed analysis, given that it is decontextualized, and it 
acquires its relevance largely through government policies and people's real-world knowledge. It does not in itself constitute a programme, and it is not legally binding. On the other hand, it is the most memorable and universally recognized articulation of official dogma. Furthermore, it carries a unique symbolic weight, since it has the approval and imprimatur of the political body whose interests it serves. Parties of all persuasions feel committed to the spirit of their slogans (if not always to the finer details of their implementation).

As Bohuslav Beneš and Václav Hrníčko have illustrated in their study of anti-regime inscriptions, spontaneous (non-official) slogans are a specific type of oral and/or pictorial and/or written form of communication which fall between folklore and literature. Beneš and Hrníčko have noted that the oral tradition involves greater variability and word play than the written tradition, although impromptu writings on walls and other objects are nearer in tone and style to the spoken word than more carefully scripted text. Folkloric inscriptions are associated with the non-ruling classes, and are thus often subversive and anti-establishment. ${ }^{18}$ Many of the pre-Communist counter slogans involved puns, rhyme, rhythmic scansion, assonance, alliteration and/or colloquial language; for instance, Volte voly, volte krávy, jen nevolte klerikály! (Vote for oxen, vote for cows; just do not vote for the clericalists). ${ }^{19}$ Before the war, both written and oral socialist protestations were at least semi-folkloric, in that they represented a rejection of the status quo from below, even if these protestations were, nevertheless, sometimes managed by political parties and other organizations.

From 1945 to 1948, however, a new left-wing consensus emerged, with the result that the original transformative dimension of the socialist slogan mutated into an expression of conformity. Such was the desire of the establishment to control the direction of society that a new Ministry of Information (Ministerstvo informací) was set up to oversee official propaganda. ${ }^{20}$ Of the parties comprising the socalled National Front (Národní fronta), the Catholic People's Party (Československá strana lidová [ČSL]) (which drew ballot number two) was the least left-leaning, but even it went into the election with a socialist-sounding slogan: $K$ lepšim zitřkiom buduj spojku, demokrat jsi, volišs dvojku (Build a connection to a better tomorrow [literally: 'tomorrows'], you are a democrat, you vote number two). ${ }^{21}$ After 1948, the official slogans became even more top-down and predictable, and thereby lost much of their affective quality. The Communists' teleological world view, which was based on dialectical materialism and revolutionary romanticism (that is, what should be, rather than what was), was confronted by the realities of transforming the economy and people's lives. The slogans' lack of original or critical perspective was in stark contrast to the questioning and imaginative folkloric slogans which greeted both the Soviet-led occupation in 1968 and the unravelling of Communism in 1989. ${ }^{22}$ Unlike the counter slogans of 1968 and 1989, the official slogans were almost completely devoid of verbal wit and literary creativity.

In terms of style, the Party slogans changed little throughout Communist rule. They tended to be schematic and formulaic, as characterized by lexical repetition (for example, Volíme socialismus. Volime mír [We vote for socialism. We vote for peace]); syntactic parallelism (Buduj socialismus, odhaluj reakci [Build socialism, expose the forces of reaction]); fixed phrases ( $V \check{c}$ ele $s K S \check{C}$ [Led by the KSČ]); exclamations ( $A t^{\prime} z ̌ i j e$ [Long live]); elliptical devices, especially the omission of verbs (Kombajn - tank míru [The combine harvester - the tank of peace]); and abstractions and nominalizations, such as dovršeni (completion) and prekročeni (overfulfilment). The use of catchy (semi-)rhyme and rhythm persisted into the early 1950s, as in Jsme mládež nová, mládež gottwaldova (We are the new youth, Gottwald's youth), and Dưsledná jarovizace - cíl naši práce (Consistent vernalization - the aim of our work), but thereafter largely disappeared. ${ }^{23}$ The overall tone of the slogans was one of familiarity, with frequent direct appeals to the public (Neváhej. Vstup do JZD! [Do not hesitate. Join the Farming Cooperative], and Stan̆te se propagátory komunismu! [Become propagators of Communism]). Yet, they largely avoided colloquial morphological, syntactic and lexical features, lest these detract from the seriousness of their message. Comparatives or superlatives were sometimes employed for hyperbolic effect, as in Pevnějš́ socialismus trvalejši mir (More solid socialism, more enduring peace), and Rudé právo - největši a nejčtenějši (Rudé právo - the biggest and most read). Exclamation marks, as in Jdeme cestou miru! (We are following the path of peace!), were also used to make the message appear more emphatic. Very few slogans were couched in the 
form of questions, as these might have invited unwelcome responses, and virtually none contained epistemic modality, which might have cast doubt on the Party's confidence in its constative propositions.

\section{The Functions of the Political Slogan}

In the context of Marxism-Leninism, the authority of the slogan was derived from the power of the Party elite, who in turn owed their status to the military and political might of the Soviet Union. Each slogan that appeared in a public space bore the explicit endorsement of the Central Committee or, in the case of May Day parades, of organizations answerable to it, including Ústřední akční výbor Národní fronty (Central Action-Group Committee of the National Front), Komise pro organizaci celostátních oslav (Commission for the Organization of All-State Celebrations) and Ústřední májová komise (Central May Day Commission). It thus had an impact which surpassed that of virtually all other forms of public proclamation. The slogan constituted one of the most unambiguous types of speech act in terms of its desired effect.

J.L. Austin has distinguished between three kinds of speech act: the 'locutionary act' (the literal or ostensible meaning of an utterance); the 'illocutionary act' (the user's intended or pragmatic meaning), including 'performatives' such as ordering, bequeathing and promising; and the 'perlocutionary act' (the actual or probable effect of the 'illocutionary act' on its addressees). ${ }^{24} \mathrm{John}$ R. Searle, elaborating on and extending Austin's work, has accentuated the importance of the intention of the illocutionary act, and hence the concepts of 'illocutionary force' and 'perloctionary effect'. ${ }^{25}$ In respect of the slogan, its illocutionary force, and especially its perlocutionary effect, frequently exceeded in importance the literal meaning of the utterance. Yurchak argues that binary accounts of socialism, based on truth and fallacy, fail to recognize the performative dimension of authoritative language, and reduce it to the purely constative. ${ }^{26}$ A slogan such as Společný výmlat metla na vesnické boháče (Collective threshing - the cane with which to thrash the village toffs), from the early 1950s, entails a constative element - collective agricultural endeavour is the best way to overcome the self-interest of the kulaks. But its perlocutionary effect resides in the function of the warning that it 'performs'. More important still, in illocutionary terms, its stark message serves to highlight the Party's uncompromising resolve. It does not in itself effect the action that it proposes, but it foregrounds the regime's value system, and intimates the lengths to which it will go to achieve its goals.

Xing $\mathrm{Lu}$, in her analysis of Chinese slogans, argues that one of the primary functions of political discourse is to establish frameworks which stifle freedom of thought. ${ }^{27}$ As long as the Party can define and delimit the scope of the political debate, its imposed hegemony cannot be seriously challenged. In Philip Wander's description of ideological criticism and dogmatism, on which Xing Lu draws extensively, this 'discourse' includes not just the speaker (that is, the Party hierarchy) and its addressees (lower-ranking Party members and the general public, especially workers), but also the disenfranchised 'Third Persona' (objectified, dehumanized, political outcasts) ${ }^{28}$ In other words, it is a closed one-way form of communication, which implicitly renders a large number of unnamed individuals (never the 'masses') silent and invisible. The slogan, perhaps more than any other rhetorical medium, disconnects those who are politically acceptable from those whose social background or ideological profile makes them personae non gratae. This group comprises not only vast numbers of ordinary people, but also party members whose commitment to Marxism-Leninism may be wavering, including the more than 90 per cent who (initially at least) expressed disapproval of the Soviet-led occupation in $1968 .^{29}$

The division of society into 'us' and 'them' is reflected in the vocabulary employed to demean and isolate those who did not share the values of the regime. Typical is the use of the noun parazit in the 1950s in slogans such as JZD - vesnice bez kulaku a parazitu (the farming cooperative - a village without kulaks and parasites), as well as pejorative expressions such as protistátní živly (elements opposed to the state), povaleči (loafers), ztroskotanci (down-and-outs), žalostné figurky (woeful figures) and, most explicit of all, bývalí lidé (former people), used internally by the Secret Police (StB).$^{30}$ There was no right of redress, and there were no formal mechanisms by which to engage in 
any kind of dialogue with these terms of reference. Röhrich, drawing on John B. Thompson's concept of fragmentation, notes that "The fragmentation of the world or its polarization into groups ["us" and "them"] is one of the basic methods of maintaining the predominance of a leading group in society". 31 Many Czechs must have felt that the epithet $O$ nás bez nás (About us, without us), used of the Munich Agreement (or 'Betrayal', as they would have it), and presumably influenced by the slogan 'Nothing About Us Without Us!' (Latin: 'Nihil de nobis, sine nobis'), equally described their leaders' treatment of them under Communism.

Vladimír Macura uses the term 'jejich jazyk' (their language) to describe the language of the regime's apologists, which most ordinary people found alien and unacceptable. ${ }^{32}$ This binary opposition between 'us' and 'them' accurately reflects the dichotomy established in official rhetoric, which served to 'otherize' anyone who questioned any aspect of Party doctrine or leadership. František Črmák adopts the same paradigm in his distinction between the 'V-jazyk' ('V-language') (jazyk vládnoucich, vládcu [the language of those who rule, the rulers]), which includes the Party's catchphrases and shibboleths, and 'O-jazyk'('O-language') (jazyk ovládaných [the language of the ruled]), which frequently indicates discontent with the Communist system. ${ }^{33}$ The 'V-language' contained many of the more obvious clichés of Soviet speak, which require little further discussion here; for instance, Pryč s pravicovými oportunisty a přsluhovači amerického imperialismu (Away with rightwing opportunists and lackeys of American imperialism). ${ }^{34}$

While almost no one employed the Party's affected rhetoric in private conversation, it was part of the professional jargon of apparatchiks. ${ }^{35}$ Such was the deontic authority of the 'V-language' that even those who actively opposed the status quo sometimes drew on the Party's terms of reference either to reinforce their own anti-establishment message or to accentuate the legitimacy of alternative interpretations of socialism. The range of intertextual and interdiscursive allusions varied widely, according to the nature of the dissent and its likely repercussions, but examples such as Studenti všech fakult, spojte se! (Students of all faculties, unite!) were not uncommon. Only in 1968, when the reformist wing of the Communist Party briefly acquired political authority, did the official slogan begin to take on some of the transformational characteristics of a popular folkloric revolt. During the Prague Spring, especially in the May Day Parades of 1968, even sceptically minded citizens readily endorsed the spirit (or maybe the potential) of platitudes such as $A t^{\prime} \check{z}$ ije KSČ́! (Long live the KSČ! [Communist Party of Czechoslovakia]).

The Marxist-Leninist slogans contributed to a clearly defined semiotic system, with its own carefully prescribed vocabulary and repeated categorical assertions, whose substance was of lesser importance than its symbolism. A major component of this system was what Michael Calvin McGee has termed the 'ideograph' - an expression or collocation such as mír a pokrok (peace and progress) whose meaning (or, rather, potential meaning, as it was always culturally bound) signifies and 'contains' a unique ideological commitment. ${ }^{36}$ The use of vague abstract concepts added a degree of gravitas to the slogans, but did not contribute in any way to broader political discussion. Indeed, over time they became semantically largely redundant. Many, but by no means all, of the well-worn phrases and ideographs were full or part translations from Russian; for example, světu mír from miru mir (peace to the world) and splníme plán from vypolnim plan (we will fulfil the plan). The symbols of Communist power were, of course, not confined to the written or spoken word. Numerous other signifiers, including statues, busts, the red star, the Soviet flag, the hammer and sickle, the peace dove, and portraits and photos of Marx, Engels, Stalin and Gottwald, complemented the printed and verbal articulations of the Party's credo.

Many Czechs and Slovaks did not like the official propaganda, and thus subconsciously blocked out its visual and oral manifestations, especially after the initial euphoria for socialism had declined in the early 1950s. They understood that the hypernormalized phrases, which Pullmann and others have aptly called 'authoritative discourse', were shallow, emblematic and tendentious. ${ }^{37}$ They also appreciated that the Party's interpretation of reality was at variance with their own experiences. However, they reluctantly accepted its pragmatic implicatures, and heeded its semi-coded messages, for a number of reasons. First, it was in their short-term self-interest to do so. Acquiescence offered 
the prospect of career advancement, reasonable material benefits and a quiet life. They were prepared to chant and display slogans, à la Havel's allegorical greengrocer, not because they were ideologically committed, but because they considered it the most rational course of action in the unpropitious circumstances. ${ }^{38}$ The fact that the complicity was so widespread psychologically mitigated its negative associations. Second, they were afraid of the consequences of challenging the status quo. Refusal to cooperate was risky, and could have serious repercussions for one's family as well as for oneself. Most reasoned that, as long as the Party retained its hold on power, with Moscow's backing, there was nothing to be gained from protesting. Third, such was the Communists' control over the dissemination of information that many people continued to be persuaded by the ideals of socialism (if not by the Soviet model).

For all their inherent contradictions and lack of sophistication, the slogan and other forms of propaganda almost certainly left a greater impression on the collective psyche, at least at a subliminal level, than has been generally recognized. As Kabát has explained,

to extricate oneself from such a large number of monotonous communications, which encroached everywhere, and moreover in a primitive, unequivocal and repetitive form, and thus also relatively intensively, was a big problem. Let us not underestimate the efficacy of their primitive nature and their repetition. ${ }^{39}$

The effectiveness of the slogan depended not on its literary merits or its erudition, but on its constant repetition and unforgiving eristic dogmatism. The impact of this normative onslaught was massively assisted by a dearth of reliable alternative sources of information. As one Czech academic privately conceded to the author "many of us simply had nothing to compare the system with. Our impressions of the West were mixed and contradictory'. The evidence of opinion polls in both 1968 and 1989 strongly suggests that most people continued to be persuaded by socialist-type solutions. According to Emanuel Pecka, 86 per cent of Czechs in a survey by the Institute of Public Opinion, in June and July 1968, wished to retain socialism. ${ }^{40}$ Even a poll conducted several days after the start of the Velvet Revolution, on 23 and 24 November 1989, found that 45 per cent of informants still supported socialism, as opposed to 3 per cent who were in favour of capitalism. ${ }^{41}$ Whatever the negative effects of Communist propaganda on people's morale, it seems incontrovertible that aspects of its core message resonated with large numbers of ordinary citizens. Private and collective memory, sometimes complemented by selective amnesia, contributed to this psychological impact. The memories evoked by slogans existed in all three of the primary sensory modalities, as identified by Atkinson and Shiffrin: visual, acoustic and semantic. ${ }^{42}$ These differently encoded messages not only acted as a constant vindication of the Party line, but they also reinforced 'information' already fixed in the longterm memory store.

The tendency nowadays to downplay the illocutionary force of propaganda is compounded by an increasing propensity to reduce it to an object of ridicule. The advent of social media has led to the widespread circulation of emotive slogans and other forms of agitational rhetoric, which are not necessarily representative. The majority of the Czech and Slovak slogans were not as inflammatory as, say, Americké agresoři utopíme v rudém moři! (We will drown the American aggressors in a red sea) or Zrádná emigrace ve službách amerických imperialistů (Treacherous emigration in the service of the American imperialists), from the 1950s. Nor was most of the other propaganda quite as unsophisticated as a widely disseminated article from 30 July 1961, which made a series of overoptimistic claims about progress under Communism. Amongst other things, this short piece, on page 3 of the popular Czech children's journal $A B C$, predicted that when its young readers were twenty-five or thirty people would work six hours per day, there would be free urban public transport and spacious living accommodation, and by 1980 the Soviet Union would produce seven times more than the USA. ${ }^{43}$ What makes the article so noteworthy here is not the ludicrous inaccuracy of the speculation, but the unnuanced picture that it paints of Communist rule. Such examples have, of course, been circulated precisely because they are so risible, but they have the unfortunate effect of obfuscating the cultural and political realities of the socialist past. 
While the core tenets of Marxism-Leninism, such as loyalty to the USSR and the leading role of the Party, may have been largely static for more than forty years, the Communist era was not a seamless and fixed continuum. Changes in Czechoslovakia, as elsewhere in the Soviet bloc, occurred both within the context of developments in the USSR, and also, to varying degrees, independent of external factors. The Czechoslovak Communists took their terms of reference directly from their Soviet masters, and frequently used similar turns of phrase, but their propaganda also reflected the changing specificities of their own socio-political circumstances. One of the major functions of the political slogans, which will be illustrated below, was to indicate these shifts in the Party's priorities and tone at different points in time. There is a notable contrast between, say, the optimism of the slogans from the early to mid-Novotný period (1953 to the early 1960s), and the largely lacklustre slogans of the 'normalization' era (early 1969 to late 1989). ${ }^{44}$

\section{Sources and Methodology}

In order to present a comprehensive analysis of the officially sanctioned slogans, I consulted a wide range of lexicographical and other academic sources, as well as media and webpages devoted to the Communist era. I also looked at two sub-sets of slogans (not included in the main body of data): postwar slogans prior to the advent of Communism, when the KSČ already dominated the political discourse, and May Day headlines from the Party daily Rudé právo. I likewise included evergreeny which were cited at May Day parades, such as Proletári všech zemí, spojte se (Workers of the world, unite), and references to May Day where it was a discourse theme in its own right, as in At'zije 1. máj! (Long live May Day!). However, I omitted May Day slogans which were not part of the mainstream propaganda, or which related to specific industrial complexes, professions, organizations, regional and local affiliates and 'interest groups'.

The slogans cited were both spoken and written, and appeared in a variety of forums, including in carefully choreographed demonstrations, in song and verse, on the big screen before films, through radio and tannoy announcements, on street banners, public signs, posters at the workplace, matchboxes, postage stamps and badges, and as miscellaneous insignia on floats or allegorical vehicles (alegorické vozy), especially tractors and combine harvesters. Amongst the most important public 'celebrations', where sloganizing was de rigueur, were Communist Party Congresses, May Day parades and anniversaries of the Communist seizure of power in Czechoslovakia in 1948, referred to as 'Victorious February' (Vitezzný únor) on 28 February and the Communist seizure of power in Russia in 1917, referred to as 'Great October Socialist Revolution' $(V \check{R} S R)$ on 7 November.

It is beyond the remit of this study to consider in detail the interplay of picture and text, but it should be noted that, where the latter embellished the former, or vice versa, the wording was often in bright red (or in yellow or white on a red background). The visual composition of posters and placards was especially striking in the late 1940s and early 1950s when, for all their naivety and crudeness, they had a certain vibrancy and vitality. One such example is the cartoon depicting happy-looking children bearing a banner with the words Všichni do boje proti mandelince bramborové (All into battle against the Colorado potato beetle), above the caption My se však nedáme! (But we will not give up!). ${ }^{46}$ (The Colorado beetle is another of the more extreme manifestations of Communist propaganda which is often cited nowadays to highlight the absurdity of the system.) By the post-Dubček period, upbeat images adorning shabby-looking buildings acquired an almost ironic hue, although the downbeat Czechs and Slovaks were so used to the contrast between fact and fiction that the irony appears to have gone largely unobserved.

This study employs statistically based methods of analysis to evaluate the prevalence of different themes, and their ideological functions. Particular emphasis is placed on the role of specific lexical items and collocations in the creation of discrete thematic entities (hereafter called 'thematic referents'), rather than on attempting to gauge the slogans' absolute frequency of usage vis-à-vis the lexicon as a whole. In other words, the focus is not on how often a particular slogan might have been cited, but on the range of slogans cited, and the different themes that they embraced. There is, of course, no doubt that, over the entire period of Communist rule, the evergreeny were reproduced 
much more commonly than temporally specific slogans, both because of their seminal place in the hierarchy of Communist propaganda, and because of their longevity.

The corpus devised for this study comprises 585 Party slogans, includes 1,056 thematic referents, and contains 3,963 word tokens and 1,666 word types. ${ }^{47}$ The average length of each slogan is just under seven tokens, and each slogan contains a mean of slightly fewer than two thematic referents. As illustrated below, the most common tokens are socialismus (socialism) and its derivatives (134 citations), and mir (peace) and its derivatives (102 citations). The concepts of 'peace' and 'socialism' collocate thirteen times.

\begin{tabular}{|c|c|c|c|}
\hline \multicolumn{4}{|c|}{ PRINCIPAL TOKENS } \\
\hline Rank & Lemma & No. & Comments \\
\hline 1 & socialismus (socialism) and derivatives & 134 & \\
\hline 2 & mír (peace) and derivatives & 102 & \\
\hline 3 & žit (to live) and derivatives & 73 & 39 times in $a t^{\prime} z i j e$ (long live) \\
\hline 4 & náś (our) & 72 & \\
\hline 5 & práce (work) and derivatives & 62 & \\
\hline 6 & Sovětský/sovětský (Soviet) and derivatives & 49 & 27 times in Sovětský svaz \\
\hline 7 & lid (the people) and derivatives & 48 & \\
\hline 8 & $K S \check{C}$ & 38 & \\
\hline 9 & svět (theworld) and derivatives & 32 & \\
\hline 10 & jednota (unity) and derivatives & 30 & excludes $J Z D$, cited 12 times \\
\hline
\end{tabular}

The slogans are classified according to four broad time frames (or sub-corpora): (A) the period of early socialist construction and Stalinist paranoia (1948 to 1954), also known as the Ostry kurz (Radical measures [literally: sharp course]) (265 examples); (B) the post-Stalinist years (the mid1950s to January 1968) (25 examples, plus 70 or more which endured from the early 1950s); (C) the two decades of normalization after 1968 (89); and (D) the socialist era taken as a whole (from 1948 to 1989), in the case of the 'perennial' and other more generalized slogans whose exact dates of usage are unclear or overlap significantly (206). One or more defining theme has been attributed to each slogan, based on 22 recurrent motifs, with a separate category for the handful of miscellaneous examples which do not fit into the paradigm. ${ }^{48}$ The numbers cited for each time frame are inevitably only indicative, but they are sufficiently accurate to allow for the identification of overall patterns. (For statistical details of the thematic referents, see below.)

Sometimes it is helpful to draw more precise distinctions within the phases specified. For instance, Jiří Knapík, Martin Franc, et al., have proposed the following temporal divisions for the pre-1968 period: 1948-50 (establishing the system); 1951-53 (crisis in the system); 1954-56 (changes to the regime's priorities, also known as the Novy kurz [New measures]); 1957-60 (the schizophrenia of the system); 1961-63 (economic problems); and 1964-67 (towards a consumer society with 'a human face'). ${ }^{49}$ The schema for 1969 to 1989 is arguably more straightforward: spring 1969 to spring 1971 (restoring 'normality'); spring 1971 to spring 1987 (maintaining the status quo); and mid-1987 to late 1989 (responding cautiously to perestroika). Slogans from the Dubček period which are associated with reform Communism are outside the scope of this article, since they effectively represented opposition to the hegemonic model; for example, Novou politiku lze délat jen s novými lidmi (You can only do new politics with new people).$^{50}$ So, too, are the handful of pro-Soviet slogans following the Warsaw Pact intervention, such as Pražane! Zastav provokatéra! (Citizen of Prague! Stop the provocateur!), because they were in response to exceptional circumstances, and did not form part of the Party's seminal discourse.

The next part of the article is devoted to contextualizing the slogans of the ideologically charged preCommunist period (1945 to 1948), which do not appear in the main corpus. It is important to look at the immediate post-war years, since they help us to understand the subsequent era of Communist rule. This is followed by a brief periodization of recurrent thematic entities. The focus then switches to a 
more in-depth discussion of the Party slogan as an index of political change across and within the four specified time frames, with a particular emphasis on the use of repetition to establish conceptual hierarchies. The analysis aims both to shed new light on the political slogan as a changing form of ideological ritual, and also to draw attention to examples which in some way or other offer a more comprehensive and nuanced representation of usage.

\section{The Pre-1948 Context of the Communist Party Slogan}

Klement Gottwald indicated a shift in direction for his fellow Communists as early as December 1929, when he endorsed the Comintern's 'class against class' ideology. This is perhaps most graphically illustrated in two oft-cited remarks from his first speech at the National Assembly: 'jednoho dne zatočíme s vámi právě tak, jako zatočili ruští bolševici s carem, s buržoasií i $\mathrm{s}$ Kerenským' (one day, we'll sort you out the way the Russian Bolsheviks sorted out the tsar, the bourgeoisie and Kerensky), and 'My se od ruských bolševiků do Moskvy chodíme učit, jak vám zakroutit krk' (We go to Moscow to learn from the Russian Bolsheviks how to wring your necks). ${ }^{51}$ His message was in contrast to the more conciliatory tone of most of the political oratory in the First Republic (1918-38) - a period dominated by Tomáš Masaryk and a coalition of parties, whose leaders were known collectively as the 'pětka' (the five) ${ }^{52}$ From the mid-1930s, the Communist Party purged Trotskyists and other 'undesirable' elements from its ranks, and increasingly followed the Soviet model, as evidenced by slogans such as Rudá armáda je naše armáda (The Red Army is our army), and Ne Masaryk, ale Lenin! (Not Masaryk, but Lenin!). ${ }^{53}$ However, despite the economic crisis of the early 1930s, and a series of strikes under banners such as Ani muže ze závodu - ani halére ze mzdy! (Not a man from the factory - not a penny from his wages!), support for the Party barely increased. ${ }^{54}$ Many of the early slogans were more explicit and literal than slogans from the later socialist period, which depended for their perlocutionary effect on the force of their pragmatic implicatures.

The change in the political atmosphere immediately following the Second World War was dramatic. The pro-socialist National Front (comprising four Czech and four Slovak parties) was heavily influenced by Communist ideology. Even President Beneš, who was closely associated with Tomás Masaryk, viewed Czechoslovakia as a bridge between the East and West, and promoted a policy of socializujici demokracie (socializing democracy), which supported the nationalization of key industries and the banning of parties that had collaborated with the Nazis. ${ }^{55}$ The much-vaunted egalitarian ethos of Czechoslovak society, as reflected in the saying Všichni máme stejné žaludky (We all have the same stomachs), may also have facilitated this shift to the left. ${ }^{56}$ Pro-leftist sympathies were so strong that the KSČ was even able to appropriate non-Communist propaganda, such as Voskovec and Werich's 1938 patriotic song, Proti větru (Against the Storm), for its own ends. ${ }^{57}$

In the 1946 election, the Czech Communist Party achieved 40 per cent of the vote in Bohemia, Moravia and Silesia, and, together with the Slovak Communists, 38 per cent of the vote in Czechoslovakia as a whole. The KSČ enjoyed the symbolically important advantage of drawing number one in the ballot, and exploited it to good effect with slogans such as První v boji, první $v$ práci, první v republice (First in the battle, first at work, first in the Republic), and $S$ čislem $1 \mathrm{k}$ lepšim zitřkuim (With number one towards a better tomorrow). ${ }^{58}$ They appealed directly to anti-German sentiment, as in Květen 1945 Nezapomeň! (May 1945 Do not forget!), and Oběti nacismu volaji po prísném potrestáni (The victims of Nazism demand harsh punishment), and supported campaigns to strengthen the country's defences, as in Pojd's námi budovat pohraniči (Come and build the borderlands with us). Amongst the various slogans that sought to highlight their credentials as a trustworthy and patriotic member of the governing coalition were Stojíme pevně za vládou národní fronty (We stand firmly behind the government of the National Front), and Vlastenko a vlastenče s dưverrou vol KSČ! (Male and female patriots, vote KSČ with confidence!). The implicit sub-text of the last two slogans ('we, the Communists, recognize that some of you regard us with suspicion, and we acknowledge your concerns') requires no further elucidation. Beneš and Hrníčko describe the postwar years as 'an era of state propaganda in a professional notice-board style, when all nonprofessional inscriptions were automatically regarded as anti-state'. ${ }^{59}$ In other words, the folkloric slogans were viewed as overtly subversive, and were strictly confined to factions which did not endorse the National Front. 
Perhaps critically, in 1946, the Communists trumpeted security and employment, as in Naše práce zvýśi blahobyt národa (Our work will increase the prosperity of the nation) and, most enduringly, Republice více práce - to je naše agitace (More work to the Republic - that is our rallying cry), often attributed to Gottwald, but probably thought up by another high-ranking Party member, Vilém Kún. Note the rhyme-like quality (prácelagitace), which was conspicuously absent from most of the later slogans. Such was the centrality of the idea of labour that it often featured in the late 1940s on matchbox labels, in expressions such as práci čest (honour to labour), which was later exalted in the official workplace greeting čest (práci), ${ }^{60}$ and Dva roky práce - 1947, 1948 dva stupně $k$ blahobytu (Two years of work - 1947, 1948 two stages towards prosperity). The strong plea for national unity was in keeping with the Communists' advocacy of a gradualist Czechoslovak path to socialism (československá cesta $k$ socialismu), but, as H. Gordon Skilling has pointed out, this policy was abandoned soon after the Communist takeover in 1948, in favour of complete subordination to Moscow, under the slogan Sovětský svaz - náš vzor (the Soviet Union - our model). ${ }^{61}$

The 1946 message was largely uncontroversial, and appealed to a progressive-minded consensus. The patriotic socialist slogans may not have had a decisive role in the Communists' 1946 election victory, but they strengthened their supporters' resolve, and contributed to an impression of unstoppable political momentum. Although the Communist seizure of power in February 1948 was by no means universally endorsed, the opposition was neither powerful enough nor sufficiently coordinated to mount a serious challenge. The National Front continued to exist in name, but the other parties were effectively taken over by Communist sympathizers, while the Social Democrats merged with the Communists later in 1948. The creation of a de facto one-party state, on strict Marxist-Leninist lines, gave the Party free rein to pursue its own agenda, and to impose subordination through the authority of the official word.

\section{Thematic Referents as a Reflection of Change Under Communism}

This section of the article addresses in greater detail political slogans from 1948 to 1989, with a view to painting a more nuanced picture of Communist propaganda over time. It does not consider all the thematic categories identified, but instead highlights examples that illuminate the development of the socialist narrative. The analysis shows that the regime was more responsive to changing social and political conditions than has been generally recognized, especially prior to 1969. New slogans appeared, to fill semantic and ideological gaps, and old slogans disappeared, for a variety of reasons. Some slogans vanished because they had become functionally obsolete; for example, campaignfocused and antagonistic slogans from the 1950s, such as Kulak je nejzavilejši nepritel socialismu (The kulak is the most obdurate enemy of socialism). Others became taboo following Khrushchev's 'secret speech' in February 1956; for instance, Se Stalinem za mír, socialismus a štěstí našeho lidu (With Stalin for peace, socialism and the happiness of our people). Still others were discarded because their message was deemed too optimistic; especially those from the early 1960s, which referred to the victory of socialism, space exploration and overtaking the capitalist world, such as Komunismus otevřel cestu $k$ hvězdám (Communism has opened the route to the stars).

The chart below indicates the occurrence in the corpus of the different thematic referents which contributed to the Communist logocracy. There is little surprise in the hierarchy of many of the themes identified, with the future and the Party's plans, work and May Day, the Soviet exemplar and fraternal relations, and peace and democracy/socialism, proving the most common overall. ${ }^{62}$ The key concept of 'building', which occurs 43 times in the corpus (under budovat and derivatives, and stavět and derivatives), and collocates 27 times with 'socialism'/'socialist', is subsumed into the theme of the future and Party plans. ${ }^{63}$ The large number of thematic referents which transcend two or more of the temporal phases testifies to the consistency of the Party's core message. There is a strong cooccurrence of 'socialism'/'socialist' with 'building', as confirmed by the high MI-score of výstavba (building) with socialismus and socialistický. A search for the stem výstavb*, in a collocation window span of -4 to 4, yields MI-scores for the genitive forms socialismu and socialistické of 6.204 and 5.357, respectively. ${ }^{64}$ This compares with figures of 7.555 and 6.908 , respectively, in the same window span, in the much more comprehensive corpus 'Totalita'. 


\begin{tabular}{|c|c|c|c|c|c|}
\hline \multicolumn{6}{|c|}{ CORPUS } \\
\hline & $\begin{array}{l}\begin{array}{l}\text { Sub- } \\
\text { corpus } \\
\text { A }\end{array} \\
(1948 \text { to } \\
\text { mid- } \\
1950 \text { s })\end{array}$ & $\begin{array}{l}\begin{array}{l}\text { Sub- } \\
\text { corpus } \\
\text { B }\end{array} \\
\text { (mid- } \\
1950 \text { s to } \\
1968 \text { ) }\end{array}$ & $\begin{array}{l}\text { Sub- } \\
\text { corpus } \\
\text { C } \\
(1969- \\
1989)\end{array}$ & $\begin{array}{l}\begin{array}{l}\text { Sub- } \\
\text { corpus } \\
\text { D }\end{array} \\
(1948- \\
1989) \\
{[\text { Ever- }} \\
\text { greeny] }\end{array}$ & $\begin{array}{l}\begin{array}{l}\text { Full } \\
\text { corpus } \\
(1948-\end{array} \\
1949) \\
\text { [All } \\
\text { slogans] }\end{array}$ \\
\hline Number of slogans & 265 & 25 & 89 & 206 & 585 \\
\hline \multicolumn{6}{|l|}{ Themes } \\
\hline 1. Work and May Day (as a theme) & 80 & 5 & 15 & 32 & 132 \\
\hline 2. The Soviet exemplar and friendship & 19 & - & 11 & 61 & 91 \\
\hline 3. The achievements of socialism & 12 & 2 & 12 & 23 & 49 \\
\hline 4. The enemy: threats and resistance & 53 & - & 4 & 9 & 66 \\
\hline 5. The future and the Party's plans & 62 & 11 & 52 & 85 & 210 \\
\hline 6. The role of the Party, government etc. & 3 & 6 & 33 & 15 & 57 \\
\hline 7. The (working) people & 22 & 2 & 11 & 26 & 61 \\
\hline 8. Individual Communists & 19 & - & 1 & 2 & 22 \\
\hline 9. Peace and democracy/socialism & 27 & 1 & 19 & 55 & 102 \\
\hline 10. Marxism-Leninism and its principles & 2 & - & 3 & 6 & 11 \\
\hline 11. The idea of unity/solidarity & 14 & - & 16 & 24 & 54 \\
\hline 12. Appeals to pseudopatriotic sentiment & 21 & 4 & 7 & 17 & 49 \\
\hline 13. Security and defence & 10 & 1 & 1 & 19 & 31 \\
\hline 14. Thrift and recycling & 12 & - & 1 & - & 13 \\
\hline 15. Elections & 10 & - & - & 4 & 14 \\
\hline 16. Women & 6 & - & - & - & 6 \\
\hline 17. Youth & 12 & 1 & 5 & 1 & 19 \\
\hline 18. Public information & 2 & - & - & 4 & 6 \\
\hline 19. Social deviance & 3 & 3 & - & - & 6 \\
\hline 20. Food & 9 & 1 & - & 2 & 12 \\
\hline 21. Learning, teaching and reading & 13 & - & 2 & 4 & 19 \\
\hline 22. The importance of being resolute & 7 & - & 5 & 9 & 21 \\
\hline 23. Miscellaneous & 4 & 1 & - & - & 5 \\
\hline Number of thematic referents & 422 & 38 & 198 & 398 & 1,056 \\
\hline
\end{tabular}

In the period from 1948 to the mid-1950s, a significant proportion of the slogans served as locutionary speech acts (that is, they conveyed information or offered practical advice), although more exhibited the characteristics of illocutionary acts (for instance, they gave implicit warnings, issued covert threats and announced thinly veiled intentions). Several motifs stand out statistically, including work and May Day as a theme (60 per cent of all the slogans attributed to this thematic category); the threats posed by the enemy and resistance to them ( 80 per cent of the total in this category, but surprisingly under 13 per cent of the thematic referents in sub-corpus A); and the glorification of individual Communists, with Stalin's and Gottwald's names being cited sixteen and fourteen times, respectively (86 per cent of the mottoes in this category). Most of the references to the contribution of women, and many of the allusions to youth, such as Milion členů ČSM - milion mladých budovatelu socialismu (A million members of the Czechoslovak Union of Youth - a million young builders of socialism), are found in this era. Other themes which are especially prevalent in the Stalinist period include security and defence (indicative of the paranoia of the system); food (reflecting shortages and agricultural reform); the efficient management of material resources (relating to economic problems); and learning, teaching and reading (in response to the educational needs of the working class). By contrast, appeals to patriotic sentiment (within a pro-Soviet 'internationalist' context), and references to the (working) people, are roughly evenly distributed throughout the corpus. 
The immediate post-Stalinist years were to some extent a continuation of the early 1950s, with the same doctrinaire language, but without the same degree of vitriol and obsessive mistrust of others. Gone were the more extreme axiological contrasts between good and evil, as were slogans relating to more targeted campaigns, including collectivization and the promotion of key industries. The denotative aspect of the slogan (especially its informational sense) was increasingly subordinated to the connotative aspect, with less emphasis placed on the negative, and more on the aspirational. In terms of speech act theory, the locutionary function of the utterances was diminished, while selected illocutionary functions were accentuated. Specifically, by the middle of the 1950s, the more controversial and time-limited slogans started to give way to a revitalized vision of the future, based on economic progress and increased competition. This vision highlighted, in particular, the scientific and technological self-sufficiency of the Soviet Union, as exemplified by the publication Vyprávéni o ruských vynálezcích a objevitelích (The Story of Russian Inventors and Discoverers). ${ }^{65}$ The official socialist rhetoric persisted into the 1960s with many of the tropes of the previous decade, but it was confronted by a strong counter-culture, especially after 1963, and by growing opposition from within and outside the Party.

The subsequent period of relatively hard-line, but pragmatic, Communist rule, beginning in 1969, was dominated by the efforts of the KSČ to reassert and maintain its control, and to promote a new political programme based on traditional Marxist-Leninist ideology and the old Soviet model (but without the same emphasis on Soviet science and technology). ${ }^{66}$ Crucial to achieving these objectives was the authority of the 'centre', as illustrated by slogans relating, inter alia, to the role of the Party, the government and other state institutions. Underpinning Husák's 'normalization' policy (generally referred to officially as konsolidace [consolidation]), were the ideas of unity and solidarity, and the need for resolution, as reflected in several of the slogans of the time. ${ }^{67}$ These slogans again drew attention to the achievements of socialism, but they played down the contribution of individual Communists (even though the validity of the 'Gottwald way' continued to be asserted in other Party propaganda). ${ }^{68}$ The largely abstract nature of these utterances detracted from their impact on a literal level, but foregrounded their intended (illocutionary) effect. A simplified version of their covert message would be along the lines of 'the conservatives are back in charge, and we will not deviate from Party policy'. While the majority of the slogans were not topic-focused or reactive, the mid1970s saw a slightly increased emphasis on the arms race, and in the late 1980s somewhat greater attention was paid to economic restructuring, and to improving quality. Interestingly, the capitalist enemy was referred to less in the well-known slogans than in other forms of propaganda, and probably less so than in the Soviet slogans of the time. It was no longer easy for the KSC to promote a coherent anti-Western message which did not invite invidious comparisons with the situation at home. It was even harder to persuade the increasing number of sceptical Czechs and Slovaks who had visited the USSR that the Soviet model was something to which they should aspire.

The propagation of quintessential catchphrases (from 1948 to 1989) contributed to a sense of natural organic growth. This was especially evident in slogans such as Buduj vlast - posilís mir! (Build the country, and you will strengthen peace!), which looked to the future. Amongst the evergreeny, pride of place went to the slogans Proletári všech zemí,spojte se (Workers of the world, unite), and Se Sovětským svazem na věčé časy (a nikdy jinak)! (With the Soviet Union for ever more [and never otherwise]!). In common with most of the slogans in sub-corpus D, these generalized mantras were frozen, and avoided reference to time-specific policies. Many alluded to the Party's plans, but none offered concrete solutions to problems or alternative visions of the future. Others spoke of the victoryof socialism and peace, as in Leninskou cestou za nová vítězství socialismu a míru ve světě (Taking the Leninist path to new victories for socialism and peace in the world), but again gave no indication as to how these might be achieved. The slogans in this category did not so much seek to change people's views of reality as to reinforce an impression of continuity, inevitability and inviolability.

\section{The Period of Early Socialist Construction and Stalinist Paranoia (1948 to 1954)}

In the early years of socialist rule, the Communists ruled through an odd combination of fear, uncompromising resolve, suspicion, pseudo-patriotism and official joy. These seemingly discordant 
approaches to governance were perhaps most clearly articulated in the propaganda campaign which accompanied the first parliamentary elections under Communism, in May 1948. Typical were slogans such as Hlásej socialismus, potlačuj vše nekomunistické, znič zrádce (Vote for socialism, suppress all that is non-Communist, destroy the traitor); Kdo má republiku rád, bude pro ni hlasovat! (Those who like the Republic will vote for it!); and S jednotnou kandidátkou - vpřed k štastné budoucnosti (With the united list of candidates - forward to a happy future). Equally worthy of note was the implicit castigation of opponents of the new regime, as in Kandidátku vládě, bilý listek zradě ([Choose] the list of candidates for government, the blank [literally: 'white'] ballot paper is for treachery). Especially eye-catching and chilling was the poster which read Bílé lístky - černé úmysly (Blank ballot papers black intentions), alongside the words Mnichov (Munich), Rozvrat (Disorder), Návrat Němcü (Return of the Germans) and a picture of a hand holding a dagger. The last two slogans were distinguished by their effective use of language, more akin to folkloric register - the former contained a near rhyme (vládělzradě); the latter had a catchy rhythm, and juxtaposed 'black' and 'white'. As illocutionary acts, their message could not be clearer - those who abstained were synonymous with the traitors of 1938.

Despite the barely veiled threats, 10.8 per cent of the electorate declined to vote for the National Front in 1948, compared with just 0.8 per cent in $1946 .{ }^{69}$ The decision of the Communists to acknowledge the scale of the opposition is, at first glance, surprising. Yet, any other result would have lacked credibility, and would have undermined the rationale for the subsequent campaign against supposed enemies of the state, the so-called zostrováni trídniho boje (sharpening of the class war). ${ }^{70}$ The Party needed the existence of adversaries and prevaricators to justify imposing its will on the people. Throughout the early years of Communist rule, any equivocation was seen as an act of overt betrayal, as indicated by slogans such as Ten, kdo stojí na chodníku, nemiluje republiku! (Anyone who is an onlooker [literally: 'stands on the pavement'] does not love the Republic), and Ten, kdo stoji na chodníku, podporuje Ameriku (Anyone who is an onlooker supports America). By the time of the 1954 elections, which were fought under slogans such as Hlas pro kandidáty národní fronty je hlasem pro mír a socialismus (A vote for the National Front is a vote for peace and socialism), just 2.6 per cent had the courage or inclination to vote against the National Front, or to submit blank or invalid ballot papers. ${ }^{71}$

Perhaps the most successful aspect of early Communist propaganda was the reinforcement of the Soviet role in the liberation of Czechoslovakia and the restoration of peace. This helped both to legitimize deference to the Soviet people and state, and to vindicate the authority of Marxist-Leninist dogma. Slogans such as Zdar sovětské armádě - osvoboditelce! (Hail the Soviet army - the liberator!) had widespread validity in the early 1950s, and retained some currency up until the Prague Spring, when the Soviet liberator was suddenly transformed into an occupier (in the view of the vast majority). ${ }^{72}$ Subsequent expressions of gratitude to the Red Army, such as František Zálešák's attractive-looking poster from 1970, Sláva 25. výroči osvobození Československa Sovětskou armádou! (Glory to the 25th anniversary of the liberation of Czechoslovakia by the Soviet army!), inevitably lacked the same resonance. Other slogans which eulogized the Soviet people, including Naším zářným vzorem jsou sovétští lidé (Our shining example is the Soviet people), or linked Soviet power to peace, as in Se Sovětským svazem za mir, za socialismus (With the Soviet Union for peace and socialism), likewise rang hollow after 1968. The motif of peace is cited 27 times in sub-corpus A, and 102 times in the corpus as a whole ( 9.5 per cent of all thematic referents), including three times in the phrase boj za mír (struggle for peace). A search for $b o j^{*}$, in a window span of -4 to 4 , yields an MI-score for the collocate mir of 7.424, compared with 7.728 in 'Totalita'. Such was the importance of the notion of peace in Communist myth-making that even the Western borders, whose primary ideological and geopolitical purpose was to isolate the socialist bloc from capitalist democracy, were attributed an irenic function: Naše západní hranice - hranice socialismu a míru (Our Western borders - the borders of socialism and peace).

The Communist lexicon was characterized by the juxtaposition of countless expressions of peaceful intent with militarized rhetoric, as evidenced by the thirty-three citations of boj (fight) and its derivatives, and the seven citations of obrana (defence), in the corpus. ${ }^{73}$ At its most extreme, in the 
Stalinist era, the language was violent and bellicose, as in Smrt válečným štváčũm (Death to warmongers), and Válečné štváče zalijeme žhavou ocelí (We will pour red-hot steel over warmongers). The constant evocation of the threat of revanchism perfectly served the Party's interests, and tapped into the public's continued mistrust of the Germans. Occasionally, the question of industrial output was linked specifically to the defeat of irredentism, as in Každá tuna oceli - rána válečným štváčum (Every ton of steel - a blow to warmongers) - where the signified has to be understood in the context of the Council for Mutual Economic Assistance's campaign to promote the military capabilities of the Soviet bloc.

Sometimes the early rhetoric, which formed a staple part of the propagandists' own lexical repertoire, must have sounded excessively opaque to ordinary people. The use of obscure Soviet-style vocabulary helped to reinforce a new sense of direction, implied an expression of loyalty to the USSR and imparted a degree of pseudo-gravitas to otherwise trite-sounding proclamations. Amongst the more striking examples from the early 1950s (which included Russian loanwords and calques, highlighted in bold) were Budeme ještě více čerpat ze zkušeností sovětských dělniků a techniků, stachanovců a zlepšovateli̊ (We will draw all the more on the experiences of Soviet workers, technicians, Stakhanovites and innovators), and Čest a sláva úderníkům - predním bojovníkům za mír (Honour and glory to shock-workers - the front-line peace-fighters). The substitution of the copula by the dash in the second slogan, and elsewhere, may have been influenced by Russian, which lacks a present tense form for the verb 'to be'. It also accentuated their difference from everyday usage, and added to their rhetorical 'punchiness'.

Particular attention, especially in the early years of Communist rule, was paid to identifying and confronting the enemy. As Nicholas Jackson O'Shaughnessy has pointed out, 'propaganda is a consequence of our need for enemies: they are not just there but necessarily there: they give coherence and definition to our values and they motivate us to action. They provide someone to blame when things go wrong' ${ }^{74}$ In the world of the ideologues, the ubiquitous foe was deemed to be especially active and malevolent in the economic sphere. The dangers of industrial and state espionage were highlighted by well-known slogans such as Nemluv o tom co děláśs! Nevíšs, kdo tě poslouchá! (Do not talk about what you are doing! You do not know who is listening to you!), which echoed British war-time posters such as 'The enemy is listening', and Naši vesnici americký agent neprojde (The American agent will not pass through our village). Anti-American sentiment appears, however, to have had relatively little impact, as there was no historical precedent for people to dislike the USA. Not only was there a large Czech and Slovak diaspora in America, but the Americans had been instrumental in the foundation of the Czechoslovak state, and the American army had liberated Plzeň in 1945. Amongst the numerous slogans which targeted the opponents of collectivization, as part of Akce K (Operation K), from November 1951 to the summer of 1953, were Kulak - škudce JZD (The kulak - the pest of the farming cooperative), and Pozor na vesnické boháče a spekulanty! (Beware of the village toffs and speculators!).

The most focused propaganda campaign of the early Communist period related to agricultural reform, as prioritized by Gottwald at the Ninth Congress of the KSČ in 1949 with his declaration 'Nebude u nás socialismu bez prechodu venkova k socialismu' (there won't be socialism here without the transition of the countryside to socialism). Slogans, whose perlocutionary force was employed in the service of this campaign, included Agresorum navzdory vykopeme brambory (We will dig up the potatoes in spite of the aggressors); Žně - sebeobrany národa (The harvest - the nation's self-defence); and Méně mezí, víc koláčù (The fewer the baulks [between fields], the more cakes there are [to eat]). ${ }^{75}$ The theme of food occurs ten times in sub-corpus A, and represents over three-quarters of all the occurrences in this category. Amongst the slogans where the locutionary function is pre-eminent (that is, where their principal meaning is denotative) are several which warn of the need for vigilance in the protection of food supplies: Chraňte potraviny před mouchami! (Protect edibles from flies!); Obilí je naše zlato, nesmí nám být ohněm vzato (Grain is our gold, it cannot be taken from us by fire); and Toulavi psi snižuji stavy lovné zvěre a ochuzuji stůl pracujicich (Stray dogs impair the population of game, and impoverish the table of the workers). For all their apparent naivety, there is nothing in many of them to suggest the oppressive nature of the regime. On the contrary, they offer common- 
sense advice, albeit expressed in rather ornate language, which is unobjectionable. After the mid1950s, food was not in such short supply in Czechoslovakia as in the USSR, and there was no equivalent to Khrushchev's corn campaign, promoted by slogans such as Kukuruza - koroleva polei (Corn - the queen of the fields), which led to the nickname 'Nikita Kukuruza'.

Despite the excesses of Stalinism, the early Communist period was a time of hope for significant sections of society, especially the young and less privileged, and of economic improvement for some (not just in comparison with the period of the German occupation). The new optimism was both reflected in and promoted by slogans such as Pro lásku k svobodě, pro uskutečněni socialismu, pro lepš́ život (For the love of freedom, for the realization of socialism, for a better life); Mějme všichni úsměv v tváŕi, nás nezdolaji reakcionáři (Let us all have a smile on our faces, the reactionaries will not overcome us); and Statečnou prací upevňujeme mír a štastné zitřky (Through our courageous work we are consolidating peace and a bright tomorrow). The use of overblown emotive vocabulary, such as láska (love), úsměv (smile), statečný (courageous) and štastný (happy) was a defining feature of the rhetoric of the times. Zápotocký's currency reform in June 1953, however, led to a dramatic deterioration in many people's sense of material well-being, and to mass protests, especially amongst workers in Plzeň. ${ }^{76}$ Despite a sustained propaganda campaign, including a series of striking cartoons in the satirical journal Dikobraz, to present the losers as black marketeers and remnants of the old elite, the devaluation of the crown and the authorities' violent response to opposition seriously tarnished the Communists' image.

Much of the propaganda in the late 1940s and early 1950s embraced the value of labour, as in Roztočte kola výroby (Crank up the wheels of production), and Více vyrábíme, lépe žijeme (The more we produce, the better we live). The latter appears to draw on the pre-war Soviet slogan 'To have more, we must produce more. To produce more, we must know more' (Chtobi bol'she imet' - nado bol'she proizvodit'. Chtobi bol'she proizvodit' - nado bol'she znat'), but without the reference to improving educational attainment. ${ }^{77}$ Some of the slogans focused on specific areas of employment (especially coal mining and steel production); for example, Nejlepši chlapci jdou do dolù a hutí! (The best blokes go to the mines and iron works!); Já jsem horník, kdo je víc! (I am a miner; who is more than me!), which was also the title of a popular song; and Hornictví - povoláni správných chlapců (a děvčat) (Mining - the profession of real blokes [and girls]). The heroization of key industrial and agricultural model workers was central to the Party's propaganda efforts, and was promoted through decorations, invitations to public meetings, financial incentives and 'notice boards of honour' (desky $c t i)$ at the workplace.

A great deal was made of the potential contribution of women to the economy, as in Česká ženo, voláme tě k tvưrči práci za lepš́ zitřek národa (Czech women, we call on you to undertake creative work for a better tomorrow for the nation), and Do práce, socialistická ženo, nová společnost tě potřebuje, nic ti nebude odepreno, všechna povolání jsou ti otevřena! (Get to work, socialist woman, the new society needs you, nothing will be denied to you, all the professions are open to you!). In reality, most women had little choice but to work. The attitude of the authorities to shirkers was made abundantly clear in slogans such as Absence ujídá koláč celku (Absenteeism consumes part of the whole cake), and Kdo nepracuje, at' neji (If you do not work, you do not eat), calqued on the Russian Kto ne rabotaet, tot ne est, from Article 12 of the 1936 Soviet Constitution. ${ }^{78}$ This uncompromising stance was reinforced by the repetition of numerous pejorative terms for loafers and spongers, including absentéri, bulači, meškači and prižzivnici, and by the appropriation of the well-known proverb Bez práce nejsou koláče (No bees, no honey; no work, no money [literally: There are no cakes without work]). ${ }^{79}$

One of the frequently overlooked functions of the early denotative slogan was to encourage modes of behaviour which promoted values commensurate with responsible socialist citizenship, such as clean living, frugality, efficiency and recycling. Amongst the examples which had implications both for the well-being of individual citizens and for the economy as a whole, was the seemingly banal inscription on matchboxes I na brigádě nezapomen̆ na hygienu (Do not forget about hygiene at your temporary job, too). Other slogans accentuated the need for the careful management of resources; for instance, 
Boj proti ztrátám ve výrobé - cesta k blahobytu (The fight against losses in production - the path to prosperity); Ani zrno nazmar! (Not a grain to be wasted!); and Každý pytel obilí republiku posílí (Every sack of grain will strengthen the Republic). At least one slogan in this group stands out for its effective use of rhythm: Jenom tam se dobře daři, kde se dobře hospodaři! (You only do well where you manage things well!) (dařilhospodaři). In a similar thematic vein was the campaign of recycling, often promoted on matchboxes, which gathered momentum from the early to mid-1950s (and persisted throughout the Communist era): Se starým papírem do sběru (To the recycling centre with old paper); Všechny kosti patři do sběru (All bones belong at the recycling centre); and Starý textil patř́ do sběru (Old textiles belong at the recycling centre). On so-called 'iron Sundays' (železné neděle), people were encouraged, under the slogan Sběrem železa pomáháme bránit mír (We are helping maintain peace by collecting iron), to leave scrap metal outside their houses, to be collected by young pioneers. ${ }^{80}$

The promotion of good husbandry, which seems strikingly modern in its conception (even if it was motivated by harsh economic realities, and sometimes acquired the characteristics of war-time mobilization), enjoyed some degree of success. Far less successful were the state's attempts to reduce the consumption of alcohol, as exemplified by slogans such as Opilství je buržoazní přežitek a sabotáž pétiletky (Drunkenness is a bourgeois anachronism, and an act of sabotage against the five-year plan), and Stalin's proclamation Je čas soudruzi skoncovat s alkoholem! (It is time, comrades, to dispense with alcohol!). ${ }^{81}$ It was, after all, rumoured that Gottwald himself had a serious drink problem. After the 1950s, relatively little attention was paid to reducing alcohol consumption in Czechoslovakia, unlike in the Soviet Union where the anti-alcohol campaign persisted throughout the socialist era. ${ }^{82}$

The attitude of the Communist authorities to education was ambiguous. On the one hand, it replaced the traditional role of the family and the church, and offered the potential to help mould a new type of person (akin to the idealized Soviet man). As such, its political and economic benefits were lauded in public campaigns. Indicative were slogans such as Kdo se uči v zimě, v létě více sklidí (Those who study in the winter will yield more in the summer); Po práci chléb a knihu (After work, it is time for bread and a book); and Rudé právo - pomocník výstavby socialismu! (Rudé právo - a helper in the construction of socialism!). Even more explicit was Zdeněk Nejedlý's slogan Výuka modernich dějin se musi zlepšit (The study of modern history must improve), ${ }^{83}$ and Jan Jícha's poster from the mid1950s Zemédělství bez strojů a odborné literatury je jako člověk bez mozku (Agriculture without machines and specialist literature is like a person without a brain). The examples of Lenin and Stalin were also repeatedly cited, as in S leninským učením ke světlým zitřkưm (With Leninist teaching towards a bright tomorrow), and Stalin učitel narodů (Stalin the teacher of nations), as was Lenin's dictum Učit se, učit se, učit se (Learn, learn, learn).

On the other hand, the Party did not need education to the same extent as the early Soviets to promote literacy. It tended to view knowledge as a double-edged sword, which could be used against its strategic interests. This is perhaps best highlighted by the catchphrase attributed to Gottwald: Vzdéláni je zbran̆, která se za žádnou cenu nesmí dostat nepríteli (Education is a weapon, which the enemy must not be allowed to get hold of at any price). Whether Gottwald actually coined the adage is of little relevance. What is important is that it encapsulated the regime's exclusive right to determine people's educational opportunities (beyond compulsory basic school level). In effect, this meant that the children of the so-called bourgeoisie and other individuals deemed antagonistic to the system were denied the same rights as children of working-class origin. In reality, as Kevin McDermott has illustrated, the KSC found it difficult to attract graduates to its ranks ${ }^{84} \mathrm{An}$ anti-intellectual sentiment thus pervaded much of its rhetoric, as evidenced by the existence of (unofficial, but widely used) disparaging expressions for the educated, including studovat za dělnické penize (to study at the expense of the worker); ty inteligente! (you academic!); and kavárenští intelektuálové (coffee-house intellectuals).

\section{The Post-Stalinist Years (the Mid-1950s to January 1968)}

Sub-corpus B, which relates to the period from the mid-1950s to January 1968, comprises around a hundred slogans, including those that continued in general circulation from the Stalinist era, but 
subsequently disappeared. The emphasis here, however, is on the twenty-five slogans identified which are most closely associated with Novotnýs rule. Ironically, most gave little indication of his hard-line autocratic style of leadership, but reflected, instead, the aspirations of the Kremlin.

Many of the slogans in the late 1950s and early 1960s indicated a renewed optimism, in the spirit of Khrushchev's goal, expressed in 1957, to catch up with and overtake America: Dognat' $i$ peregnat' Ameriku (Dohnat a předehnat). ${ }^{85}$ Slogans such as Kupředu za vitězné dovršení výstavby socialismu v naši vlasti (Forward to the victorious completion of the construction of socialism in our land) and Dovršime výstavbu socialismu (We will complete the construction of socialism) also reflected increasing self-confidence emanating from improvements in the economy, and the success, at the Brussels World's Fair, in 1958, of the exposition 'One Day in Czechoslovakia'. While cultural and political repression persisted towards the end of the 1950s, it was on a lower scale than at the start of the decade, and was no longer a defining influence on the Party's propaganda. Novotný broadly followed Khrushchev's shift from heavy industry to consumer goods, and engaged more actively in economic competition with the West. In terms of specific economic policies, the most significant development was arguably the introduction, in 1958, of the brigáda socialistické práce (socialist work brigade), which aimed to raise educational standards, increase workers' collective responsibility and improve output, under the slogan Socialisticky pracovat,socialisticky žit (To work and live in a socialist way), again calqued on the Russian: Zhit' I rabotat' po-sotsialisticheski. ${ }^{86}$

In 1960, the title Československá socialistická republika (ČSSR) (Czechoslovak Socialist Republic) was enshrined in a new constitution, which boldly asserted Socialismus v naši vlasti zvitězil! (Socialism has won in our country!). Other mottoes in the early 1960s also referred to the victory of socialism, including the headline in Rudé právo on 2 May 1961: Vitězství socialismu v naší zemi je vitězstvím veliké věci komunismu (The victory of socialism in our country is the victory of the great Communist cause). Yet what this meant in reality was unclear. As if these claims were not bombastic enough, at the Twenty-Second Congress of the Communist Party of the Soviet Union, in October 1961, Khrushchev issued his famous declaration (alluded to earlier) that Communism would be achieved by 1980 .

Novotný's administration initially embraced Khrushchev's Panglossian vision of the future with enthusiasm, and adopted its own version of his remark Nineshnee pokolenie sovetskikh lyudei budet zhit' pri kommunizme (Today's generation of Soviet people will live under Communism), which replaced the phrase 'Today's generation of Soviet people' with 'our generation' (Ještě naše generace bude žit v komunismu). The original Communist assumption that the state would gradually give way to local community-based organizations was, however, belied by the reality of increased centralization, which contributed to a serious decline in the Czechoslovak economy by mid-1962. Following Khrushchev's removal from power in 1964, the noun komunismus was employed much more circumspectly, sometimes as a synonym for 'socialism'. Over time, explicit references to its realization were expunged from much of the narrative of the KSČ, as reflected by the fact that the term only occurs once in sub-corpus $\mathrm{C}$.

The latter years of Novotný's leadership were defined by a growing gulf between his supporters and his outspoken opponents, especially in the cultural and economic spheres, and amongst advocates of greater Slovak autonomy. The regime no longer engaged in the same large-scale witch hunts against imperialists and other enemies of the state, but focused more on maintaining its grip on the (increasingly independent-minded) media and arts. It also targeted specific 'anti-social elements', especially so-called máničky or vlasatci (longhaired men). Long hair was seen as a deliberate manifestation of dissent amongst the young, which sought, in the view of Filip Pospíšil and Petr Blažek, to split the consensus between the ruling elite (the Party and nomenklatura) and subordinate groups in society (workers, people employed in the service sector, and so on) ${ }^{87}$

Numerous campaigns against hippies, rock musicians and others were launched in the mid-1960s. The slogans in support of this campaign sometimes combined locutionary and illocutionary speech acts. For example, Vlasatým nenaléváme (We will not serve drinks to those with long hair), referring to the 
restrictions placed on them in pubs and restaurants, functioned both as a policy statement and as an implicit warning. At least one slogan exhibited a semi-folkloric quality, and a degree of intertextual awareness largely absent from other official propaganda: Dlouhé vlasy, krátký rozum (Long in hair, short in intellect), which has its origins in the old Czech legend Kněžna Libuše a Přemysl (Princess Libuše and Přremysl). The regime's opposition to máničky was revived in the early 1970s, under the slogan Mášli dlouhý vlas, nechod' mezi nás! (If you have long hair, do not come and join us!), but the Communist Party subsequently softened its approach, in recognition perhaps of the limited efficacy of its efforts, and the outmodishness of its policy. A particular difficulty for the authorities was that they could not make foreign visitors, who served as a model for many of the trends, comply with their preferred appearance code.

\section{The Normalization Era (Early 1969 to Late 1989)}

For all the shortcomings of the Novotný administration, the period from 1963 to 1968 was relatively tolerant, especially in terms of culture, when compared with what preceded it, and with the ensuing Husák era. After 1968, the Party, whose leadership was dominated by hardliners, was on the defensive, but had little to say in its own defence. As Jan Rychlík puts it, 'The Soviet occupation of Czechoslovakia and the normalization years made it very hard to find space for official Communist propaganda' ${ }^{88}$ Husák was true to his word when he told workers at the ČKD engineering company in 1969 that there would be no return to the worst excesses of Stalinism (of which he himself had been a victim), famously declaring, 'Nebudeme nikoho kráglovat ani krieglovat' (We won't bump anyone off or 'do a Kriegel'). ${ }^{89}$ Yet, the price for not 'doing a Kriegel' was large-scale moral compromise and public resentment. The Party effectively adopted the dictum 'Kdo nejde s námi, jde proti nám' (Those who do not go along with us, go against us). Specifically, it required people with any social and professional status to say whether they approved of the 'fraternal assistance' of the Warsaw Pact forces against the reformist 'counter-revolution'. The two suppositions implicit in the question allowed no scope for negotiation. Non-agreement generally resulted in demotion at or dismissal from work and/or expulsion from the Party, as well as reduced opportunities for oneself and one's closest relatives.

The political slogans no longer offered an alternative vision of reality or hope for a better future, and barely even sought to convert people to the Communist cause. Moreover, the set-piece official celebrations, with which they were increasingly associated, lacked spontaneity or genuine engagement, with many people seeking as fast an exit as possible (without drawing undue attention to themselves). However, their primary semiotic function remained undiminished. They defined the parameters of the discourse, maintained a sense of continuity with the past and served as a reminder of the enduring authority of the established order. Widespread inertia and passivity were the corollary of the imposed stability. People were permitted to disengage from most aspects of public life, and to seek 'self-realization' in the private sphere by exploiting the advantages of state protection and socialist consumerism, providing they did not rock the boat. ${ }^{90}$

Amongst the ideographs which defined this unspoken compromise between the rulers and the ruled were klid na práci (the opportunity to work in peace), klid a pořádek (peace and order) and sociální jistota (social security). Continued lip-service was, of course, paid to promoting the socialist cause, especially to the generation known euphemistically as 'Husákovy děti' (Husák's children), as in ČSSR - záruka štastného života a budoucnosti mladé generace! (The CSSR - guarantor of the happy life and future of the young generation!), but they met with a largely muted response. Appeals to their parents to build a better society through the effort of their labours, such as Poctivou a tvưrči praci ke konsolidaci naši společnosti! (Through decent and creative work towards the consolidation of our society!) and Jak budeme dnes pracovat, tak budeme zitra žit! (How we work today is how we will live tomorrow!), equally fell mainly on deaf ears. Most people felt that the post-1968 vision of the future was one based on the discredited policies of the past, and that its staunchest advocates were those most responsible for the excesses and deficiencies of the pre-Dubček era.

The Husák regime may have largely failed to rekindle socialist ardour, but it can claim significant success in its principal goal of reimposing Marxism-Leninism. Not only did the pro-Soviet faction in 
the Party reassert control, but overt manifestations of opposition were short-lived and limited in scope. The process of transition was facilitated by the continued presence of large numbers of Soviet troops on Czechoslovak soil, and by the emigration (enforced or voluntary) of many of the more vociferous critics of the regime. ${ }^{91}$ It was further helped by the relatively strong performance of the economy, particularly in the early 1970s, and by the creation of the new federal state, which placated Slovak demands for greater autonomy. For many Slovaks, slogans such as ČSSR - záśtita svobodného rozvoje Čechi̊ a Slovákư! (The ČSSR - protector of the free development of the Czechs and Slovaks!) had a much greater resonance than they did for Czechs.

The slogans of the 1970s and 1980s were, for the most part, a repetition of the trite, generalized mottoes of the pre-1968 period, such as At’žije naše dělnická tř́da a její bojový předvoj Komunistická strana Československa (Long live our working class and its fighting vanguard, the Communist Party of Czechoslovakia) from 1981. The focus was on glorifying the system, rather than on seeking to effect meaningful change. The regime continued to spend a great deal of time and money marking anniversaries, as reflected, for instance, in the slogan 40 let v čele s KSČ za nová vitezzství socialismu a komunismu (Forty years under the leadership of the KSČ for new victories of socialism and Communism). It also engaged in endless publicity about fulfilling the Party's plans, as in Nás cíl splnit usnesení XIV. sjezdu KSČ (Our aim - to fulfil the resolutions of the 14th Congress of the KSČ), from 1971. There are twenty-five citations of the noun sjezd (congress), and fifteen citations of (s)plnit (to fulfil) and its cognates, in sub-corpus C. The importance of the resolve and the unity of the Party, and of the indivisible alliance with other socialist states, is likewise reasserted in numerous slogans, including $V$ pevné jednotě KSČ a lidu za další úspěchy při budování rozvinuté socialistické společnosti (In firm unity with the KSČ and the people for further successes in the building of a developed socialist society). The noun jednota (unity) and its derivatives are cited eleven times, while pevný (firm) and its derivatives occur nine times.

Where there were differences from the past in terms of style and tone, they tended to be in response to external or economic factors. For example, the theme of peace was increasingly shaped by the threat of nuclear war. Slogans which marked this shift in emphasis included Za mír a život proti jaderné válce (For peace and life against nuclear war) (1983); Nechceme omezenou válku, chceme neomezený mír! (We do not want limited war, we want unlimited peace!) (1984); Jsme pro svět bez válek, beze zbraní (We are for a world without wars, without arms) (1985); and Nechceme hvězdné války ale hvězdný mír (We do not want star wars, but star peace) (1987). The changes in economic discourse reflected a growing awareness of the need for better methods of production, as in Kvalita a hospodárnost - základ úspěchů 5. Pětiletky (Quality and thrift - the basis for the successes of the 5th Five-Year Plan [1971-75]). The switch in the early 1980s to 'intensification', which attached greater importance still to the efficient use of resources, is identified, for instance, in the slogan Intenzivni rozvoj národního hospodárství - revolučni úkol současnosti! (The intensive development of the [national] economy - the revolutionary mission of the present times).

It was not until the late 1980s, in response to Gorbachev's initiatives in the USSR, that the Communist authorities began to advocate more radical economic reforms. Amongst the slogans that tentatively reflected the incipient changes were Cestou prestavby a demokracie za socialismus (Through restructuring [perestroika] and democracy for socialism) and Cestou prestavby hospodářského mechanismu $k$ upevňováni mírového procesu (Through restructuring the economic mechanism towards the strengthening of the peace process). Whilst some lip-service was paid to commensurate reforms in the political sphere, ideological rhetoric continued to be defined largely by the forces of conservatism. The replacement of Husák by Miloš Jakeš as Party leader, following the seventh plenum of the Central Committee in December 1987, did little to change the nature of the discourse, although external events stimulated a number of minor concessions, such as the easing of restrictions on travel abroad. ${ }^{92}$

\section{Socialism as a Whole (from 1948 to 1989)}

The perennial slogans, which constituted the essence of Party propaganda, do not require extensive analysis here, since they added nothing new to the official narrative. Suffice it to say, they uncritically 
reiterated Marxist-Leninist values, principles and aspirations, and were semantically and stylistically heavily prescribed. They did not seek to provide any information of import, and nor did they attempt to modify or even engage public opinion. Their illocutionary force resided in their constant repetition, and their evocation of a past that was heavily coloured by the Party's tendentious interpretation of history. Their meaning (that is, in practice, their connotative sense rather than their denotative sense) was derived largely from the semiotic system which they served, and in which they operated. People took the evergreeny for granted (in much the same way as the British do the monarch's head on postage stamps), and acceded to their pragmatic implicatures both for their own strategic reasons and through force of habit.

Proof of the consistency of the Party line was the enduring influence of the 1936 Soviet Constitution (op. cit.), which enshrined, inter alia, the importance of labour, socialist means of production and ownership, and the idea of centralized authority. ${ }^{93}$ The three most important themes to emerge from sub-corpus D are the future and the Party's plans, the Soviet exemplar and fraternal relations, and peace and democracy/socialism, each with over a quarter of the total citations in this category. Linked to the idea of Soviet friendship is the imperative for solidarity. Also statistically significant are work and May Day (as a theme), the role of the ordinary people, the achievements of socialism, and security and defence.

Amongst the slogans in sub-corpus D that look to the future and the Party's plans are 31 beginning $A t^{\prime}$ žije (Long live), and 4 which contain kupredu (forward). The noun socialismus and derivatives are cited 56 times; mír (peace) and derivatives, 55 times; práce (work) and derivatives, 39; Sovétskýlsovětský (Soviet), 37; náš (our), 28; and lid (the people) and derivatives, 25. Ten of the 13 references to přátelství (friendship) collocate with Sovětský/sovětský or SSSR (USSR). The importance of common purpose is accentuated, as in sub-corpus $\mathrm{C}$, through the repetition of jednota (unity) and its derivatives, cited 16 times. Ironically, perhaps, in view of the Soviet-focused and 'international' nature of the propaganda, appeals to pseudo-patriotic sentiment also feature commonly, as evidenced by the 28 citations of $n a ́ s ̌$, and 14 citations of vlast (homeland), with which náš collocates five times. The extent to which Czechs and Slovaks regarded the system as their 'own' is a matter of conjecture, especially after 1968. However, what is clear is that, until virtually the end of 1989 , most continued to view socialist rule, and its core tenets, as permanent and irreversible. The opening words of the title of Yurchak's previously cited study aptly summarized their perspective: Everything Was Forever.

\section{Conclusion}

It would be easy to dismiss the propaganda campaign, and its innumerable slogans, as irrelevant, crass and potentially even counter-productive. Personal reminiscences of the past, nearly thirty years after the end of Communism, tend to create the impression that relatively few people really believed in socialism, or accepted it as a legitimate alternative to Western capitalist democracy. Typical today are comments which mock the very proposition that people were gullible enough to fall for the deceit, and social media citations which highlight the most primitive aspects of the official rhetoric. Yet, as already indicated, the evidence of the available opinion surveys suggests that the ideals of socialism were widely endorsed throughout the Communist era. The broad acceptance of socialist values is also borne out by several (but by no means all) of the anti-hardline folkloric slogans, especially from 1968, which implicitly accepted the premises on which the system was founded; for example, Socialismus ano, mus ne (Socialism yes, necessity no), and Lenine, probud' se, Brežněv se zbláznil (Wake up, Lenin; Brezhnev's gone mad) ${ }^{94}$ Krapfl argues persuasively that, even during the Velvet Revolution, Czechs and Slovaks were initially more concerned by the deformations of Communist rule than by the nature of the political system per se, with a majority advocating some kind of compromise between socialism and capitalism. ${ }^{95}$ (It goes without saying that most people were unfamiliar with the notion of pluralism as a prerequisite for the checks and balances necessary to minimize abuses of power.)

It is not possible to determine the full impact of the authoritative discourse, and its different semiotic conventions and manifestations, on individuals' cognitive development, but psychological and anthropological research (Atkinson and Shiffrin, and Kertzer, amongst others) strongly supports the idea that long-term memory is shaped by repetition and ritual. Forty years of official propaganda, in 
the context of a society largely cut off from Western democratic traditions for half a century, had a profound influence on people's world-view. The imposed schema may well have been more a source of irritation than inspiration, but it left the public in little doubt about the priorities and values of the regime that it served. I argue elsewhere that the refusal of the Party, in the late 1980s, to polemicize seriously with its opponents almost certainly delayed the demise of Communism. ${ }^{96}$ Even if, after 1968, the slogans did not inculcate in the Czechs and Slovaks a renewed veneration of the Soviet Union, and even if they did not sell the virtues of the leading role of the Party, they nonetheless promoted the notion of socialist-style solutions, and they cast doubt on the Western model. At the very least, they helped to normalize an alternative to capitalism, which most people learnt to adapt to, despite its imperfections, contradictions and inconsistencies.

Those who lived through the whole of socialist rule can testify to the significant changes in the atmosphere that prevailed at different times. Notwithstanding the derivative and formulaic nature of the slogans, characterized by excessive stylistic uniformity, the Party rhetoric still bore witness to numerous subtle and less subtle shifts in ideology. Sometimes these developments were marked by the absence of leitmotivs from an earlier period (for instance, the paranoia of the 1950s or the optimism of the early 1960s); elsewhere, they were reflected in the introduction of new themes (such as responses to military challenges from the West or Soviet-inspired economic initiatives). Yet, at no point, not even during the relative constancy of the Husák years, did the official message cease to evolve altogether. To treat Communism and its propaganda as a static homogenous entity is to understate the range and the functions of its temporally specific features.

\section{Notes}

${ }_{1}$ For more on perceptions of the new state, and the Czechs' privileged position in it, see Mary Heimann, Czechoslovakia. The State that Failed (New Haven and London, 2009) (especially Chapter 3, 'A Troubled Democracy', 48-86). Jakub Rákosník, 'Tři cesty soudobé české historiografie komunismu', in Český a slovenský komunismus (1921-2011), ed. Jan Kalous and Jiři Kocian (Prague, 2012), 13-23, highlights the predominance of the (uniformly negative) totalitarian paradigm in the post-1989 Czech historiography of the Communist era.

${ }_{2}$ See Emanuel Pecka, 'Political Culture in the Czech Republic', in Political Culture in East Central Europe, ed. Fritz Plasser and Andreas Pribersky (Aldershot, 1996), 205-10, and James Krapfl, Revolution with a Human Face. Politics, Culture, and Community in Czechoslovakia, 1989-1992 (Ithaca, NY, 2013), 99-100.

${ }_{3}$ Jindřich Kabát, Psychologie komunismu (Prague, 2011), 74.

${ }_{4}$ R.C. Atkinson and R.M. Shiffrin, 'Human Memory: A Proposed System and its Control Processes', Chapter 2, in The Psychology of Learning and Motivation, ed. Kenneth Spence and Janet Taylor Spence (New York and London, 1968), vol. 2, 89-195. According to their categorization, memory can be divided into three structural components: the sensory register (that is, a fleeting visual image); the short-term store ('working memory', which may exist in various sensory modalities); and the long-term store (to which information has been transferred from the short-term store). Whereas all information in the former two decays and is eventually lost, the long-term store is a much more permanent repository of information.

${ }_{5}$ David I. Kertzer, Ritual, Politics and Power (New Haven and London, 1988), 9-10.

${ }_{6}$ The examples cited hereafter are all in Czech, although most of the phrases also had very close Slovak equivalents. Slovak slogans which allude to purely Slovak phenomena, such as KSS vedie národ k rekonštrukcii a budovaniu (The Communist Party of Slovakia is leading the nation towards rebuilding and construction), in 1946, or to greater self-determination, such as Najprv demokratizácia až potom federalizácia (First democratization and only then federalization), in 1968, are not considered.

7 Suffice it to mention here František Čermák, Václav Cvrček and Věra Schmiedtová, eds., Slovník komunistické totality (Prague, 2010); Jiří Pruša, Abeceda reálného socialismu (Prague, 2011); Věra Schmiedtová, Malý slovník reálií komunistické totality (Prague, 2012); '1948-1989', http://www.spominaj.sk/index.php/sluby-aprisahy/budovatelske-hesla; and 'Od propagandy k reklamě', http://www.padesatky.info/19491950/4-odpropagandy-k-reklame. 8 Ibid., 633-60 (accessed 7 September 2016.)

9 See Petr Fidelius, Řeč komunistické moci (Prague, 1998).

${ }_{10}$ Oldřich Tůma, 'Proměny komunistického režimu', in Čermák, Cvrček and Schmiedtová, Slovník komunistické totality, 9-15 (9).

${ }_{11}$ Alex Rőhrich, Ideologie, jazyky, texty. Analýza a interpretace textů Rudého práva z roku 1953 a 1975 a Práva z roku 1997 (Liberec, 2008).

${ }_{12}$ See 'Totalita', Český národní korpus, Prague, http://ucnk.ff.cuni.cz (accessed 27 September 2017). 
${ }_{13}$ See Alexei Yurchak, Everything Was Forever, Until It Was No More. The Last Soviet Generation (Princeton and Oxford, 2005); Mikhail Bakhtin, Four Essays by Mikhail Bakhtin, ed. and intro. Michael Holquist, trans. Carol Emerson and Michael Holquist (Austin, 1994); and Michal Pullmann, Konec experimentu. Přestavba a pád komunismu v Československu (Prague, 2011).

${ }_{14}$ Philip Wander, 'The Third Persona: An Ideological Turn in Rhetorical Theory', Central State Speech Journal 35 (1984), 197-216 (209-10), and Jaroslav Pažout, ed., Informační boj o Československo / v Československu (1945-1989) (Prague, 2014).

${ }_{15}$ For more on this theme, see Jan Lomíček, 'Proměny konstrukce obrazu Sovětského svazu v poválečném Československu', in Pažout, Informačni boj, 18-27, and 'Se Sovětským svazem na věčné časy? Proměny vnímání SSSR v Československu v průběhu "krátkého" dvacátého století', Sborník Národního muzea v Praze 69, nos 1-2 (2015), 5-18.

${ }_{16}$ Catherine Soanes and Angus Stevenson, eds., Oxford Dictionary of English, 2nd edn (Oxford, 2006).

${ }_{17}$ Bohuslav Havránek et al., Slovník spisovného jazyka českého, 4 vols (Prague, 1960-71).

${ }_{18}$ See Bohuslav Beneš and Václav Hrníčko, Nápisy v ulicích (Brno, 1993), 7-12.

${ }_{19}$ The noun 'vůl' (ox) also means 'silly fool'. The clericalists advocated a key role for the (Catholic) Church in politics.

${ }_{20}$ See Robert Kvaček, 'Slova na úvod', in Pažout, Informační boj, 14-16 (15).

${ }_{21}$ See František Čapka and Jitka Lunerová, 1948: Vitězný únor (Brno, 2012), 74.

${ }_{22}$ See ibid., and Jindřich Pecka, Spontánní projevy Pražského jara 1968-1969 (Brno, 1993).

${ }_{23}$ Klement Gottwald was General Secretary of the KSČ from February 1929, and President of Czechoslovakia from June 1948 to his death in March 1953.

${ }_{24}$ See J.L. Austin, How to Do Things with Words (Oxford, 1962).

${ }_{25}$ See especially John R. Searle, Speech Acts: An Essay in the Philosophy of Language (Cambridge, 1969).

${ }_{26}$ Yurchak, Everything Was Forever, 75.

${ }_{27}$ Xing Lu, 'An Ideological/Cultural Analysis of Political Slogans in Communist China', Discourse \& Society (1999) 10, no. 4, 487-508 (489).

${ }_{28}$ Philip Wander, 'The Third Persona: An Ideological Turn in Rhetorical Theory', Central State Speech Journal 35 (1984), 197-216 (209-10).

${ }_{29}$ See Zdenek Hejzlar, Praha ve stínu Stalina a Brežněva (Prague, 1991), 149.

${ }_{30}$ For further discussion of this theme, see Fidelius, Řeč komunistické moci, 156-57.

${ }_{31}$ See Rőhrich, Ideologie, jazyky, texty, 65-66, and John B. Thompson, Ideology and Modern Culture: Critical Social Theory in the Era of Mass Communication (Cambridge, 1990), 65.

${ }_{32}$ Vladimír Macura, Štastný věk. Symboly, emblémy a mýty 1948-1989 (Prague, 1992), 13.

${ }_{33}$ František Čermák, 'Slovník komunistické totality: lexémy, nominace a jejich užití', in Čermák, Cvrček and Schmiedtová, Slovník komunistické totality, 16-39 (16-17).

${ }_{34}$ For a detailed discussion of Soviet Communist rhetoric, see Michael Waller, The Language of Communism. A Commentary (London, 1972).

${ }_{35}$ For an analysis of some of the defining characteristics of Communist officialise, see Otto Exner, 'Některé charakteristické rysy úředního jazyka komunistické éry’, Naše řeč 75, no. 2 (1992), 91-98.

${ }_{36}$ Michael Calvin McGee, 'The "Ideograph": A Link Between Rhetoric and Ideology', Quarterly Journal of Speech 66, no. 1 (1980), 1-16 (7).

${ }_{37}$ Pullmann, Konec experimentu.

${ }_{38}$ See Václav Havel, Moc bezmocných (Prague, 1990).

${ }_{39}$ Kabát, Psychologie komunismu, 349.

${ }_{40}$ Pecka, 'Political Culture in the Czech Republic', 206.

${ }_{41}$ Cited by Krapfl, Revolution with a Human Face, 100.

${ }_{42}$ Atkinson and Shiffrin, 'Human Memory'.

43 The article, inspired by Khrushchev's Party Programme, was published under the title REDAKCE ABC, 'Velkolepá budova světa', ABC mladých techniků a přírodovědců, 9 (1961), 3. A slightly amended version (under the inaccurate title ' $\mathrm{Z}$ časopisu ABC - rok 1960' [From the journal $A B C$ - 1960], and without further bibliographical details) probably first appeared in (no author), 'Vtipy a frky z internetu', Kralice na Hrané (2005), 26.

${ }_{44}$ Antonin Novotný was First Secretary of the KSČ from March 1953 to January 1968, and President of Czechoslovakia from November 1957 to March 1968.

${ }_{45}$ The most detailed study of May Day parades is in French: Roman Krakovský, Rituel du ler mai en Tchécoslovaquie 1948-

1989 (Paris, 2004). Also worthy of note are Alena Černá, 'Oslavy Prvního máje na Liberecku v letech 19451989, jejich organizační zajištění a průběh’ (Diplomová práce, Technická univerzita v Liberci, 2013), and 'Propagace Prvního máje na Liberecku v letech 1945-1989', in Pažout, Informační boj, 136-73. 
46 The Communist authorities launched a mass campaign in the early 1950s claiming that the West was deliberately dropping the beetle by parachute and balloon over Czechoslovakia, East Germany and Poland, and urging people to search out and destroy the bug.

${ }_{47}$ I used the corpus analysis toolkit AntConc to calculate the data (excluding thematic referents): Laurence Anthony, AntConc,

2016, at http://www.laurenceanthony.net/software.html.

${ }_{48}$ Slogans are classified as 'miscellaneous' where fewer than five similar thematic referents were identified.

${ }_{49}$ Jiří Knapík, Martin Franc et al., Průvodce kulturním děním a životním stylem v českých zemích 1948-1967, 2 vols (Prague, 2011), 21-40.

${ }_{50}$ Alexander Dubček was First Secretary of the KSČ from January 1968 to April 1969.

51 Poslanecká sněmovna parlamentu České republiky, 21 December 1929, http://www.psp.cz/eknih/1929ns/ps/stenprot/007schuz/s007003.htm. (accessed 24 May 2017). Alexander Fyodorovich Kerensky was head of the Russian provisional government from July to November 1917.

${ }_{52}$ Tomáš Garrigue Masaryk was President of Czechoslovakia from November 1918 to December 1935.

${ }_{53}$ According to Communist accounts, their banners were systematically destroyed at May Day parades. See, for example, Věra Dvorská, 'Připravujeme se na Svátek práce', Zápisník agitátora 8 (1956), 55-61 (55).

${ }_{54}$ In the 1929 general election, the Communists gained $10.2 \%$ of the vote, and in 1935 , their vote went up to $10.32 \%$.

${ }_{55}$ Edvard Beneš was President of Czechoslovakia from December 1935 to October 1938, and from April 1945 to June 1948.

${ }_{56}$ For a discussion of this theme, see Ladislav Holy, The Little Czech and the Great Czech Nation (Cambridge, 1996).

${ }_{57}$ Cf. the 1950s' slogan Poručíme větru, dešti! (We will command the wind and the rain!), which was indicative of the kind of wishful thinking that the Party promoted at the time.

${ }_{58}$ See Čapka and Lunerová, 1948, 74.

${ }_{59}$ Beneš and Hrníčko, Nápisy v ulicích, 15.

${ }_{60}$ The phrase čest práci dates back to at least 1922, when it appeared in the song 'Píseň práce' (Work song), author unknown, which subsequently underwent various revisions.

${ }_{61}$ H. Gordon Skilling, Czechoslovakia's Interrupted Revolution (Princeton, 1976), 26.

${ }_{62}$ The theme of work is discussed in detail by Věra Schmiedtová, 'Totalitní jazyk v bývalém Československu (1948-1989), koncept slova práce', in Totalitarismus 3, ed. I. Budil and T. Zíková (Plzeň, 2007), 110-17.

${ }_{63}$ These figures include thirteen citations of the phrases ( $v y$ )stavba socialismu (the construction of socialism) and socialistická výstavba (socialist construction).

${ }_{64}$ An MI-score of 3 or more is generally considered statistically significant evidence of collocation in the case of word forms which are reasonably common.

${ }_{65}$ Viktor Nikolajevič Bolchovitinov et al., Vyprávění o ruských vynálezcích a objevitelích (Prague, 1954). See Lomíček, 'Proměny', 117.

${ }_{66}$ The programme is articulated in the document 'Poučení z krizového vývoje ve straně a společnosti po XIII. sjezdu KSČ', which first appeared as a supplement to Rudé právo, 14 January 1971.

${ }_{67}$ Gustav Husák was First/General Secretary of the KSČ from April 1969 to December 1987, and President of Czechoslovakia from May 1975 to December 1989.

${ }_{68}$ In Slovník komunistické totality, Gottwald's name has a relative occurrence of 298 ppm (and 20 ppm in its adjectival form gottwaldovský), compared with 116 ppm for Husák's name.

${ }_{69}$ See R. K. Evanson, 'The Czechoslovak Road to Socialism in 1948', East European Quarterly 19, no. 4 (1985), 469-92 (480).

${ }_{70}$ See, for example, Lenka Kalinová, Společenské proměny v čase socialistického experimentu. K sociálním déjinám v letech 1945-1969 (Prague, 2007), 120.

${ }_{71}$ In elections thereafter, support for the National Front was virtually unanimous, according to official sources.

${ }_{72}$ This is excellently illustrated in the photographic collection compiled by Dana Kyndrová, 1945 Osvobození /

Liberation, 1968 Okupace / Occupation - Sovětská vojska v Československu (Prague, 2008).

${ }_{73}$ For more on this topic, see Čermák, 'Slovník komunistické totality', 34-37.

${ }_{74}$ Nicholas Jackson O’Shaughnessy, Politics and Propaganda: Weapons of Mass Seduction (Manchester, 2004), 7.

${ }_{75}$ The images of the unploughed land between furrows (on private plots), and the cake (as a symbol of the good life), featured prominently in collectivization propaganda.

${ }_{76}$ Antonín Zápotocký was Prime Minister from June 1948 to March 1953, and President of Czechoslovakia from March 1953 to November 1957.

${ }_{77}$ Unlike in the Soviet Union, the Czechoslovak authorities did not have to overcome the problem of mass illiteracy. 
78 'Konstitutsiya (Osnovnoi zakon) Soyuza Sovetskikh Sotsialisticheskikh Respublik', http://constitution.garant.ru/history/ussr-rsfsr/1936/.

${ }_{79}$ Other proverbs assimilated by the Communists included Když se kácí les, létají trísky (You cannot make an omelette without breaking eggs [literally: When a wood is felled, the splinters fly]), which they used to justify any negative consequences of their actions.

${ }_{80}$ See Andrew Roberts, From Good King Wenceslas to the Good Soldier Švejk (Budapest and New York, 2005), 189.

${ }_{81}$ The mortality rate from liver cirrhosis rose in Czechoslovakia by $470 \%$ from 1950 to 1990 . See Rumi Kato Price, Brent Mack Shea and Harsa N. Mookherjee, eds., Social Psychiatry across Cultures: Studies from North America, Asia, Europe, and Africa (New York, 1995), 45.

82 A Soviet poster in the 1970s declared Progul'shchikam $i$ p'yanitsam pozor! (Shame to loafers and drunkards!), and from

1985 to 1987 Mikhail Gorbachev imposed partial prohibition.

${ }_{83}$ Zdeněk Nejedlý was Minister of Culture and Education from April 1945 to July 1946, and from February 1948 to January 1953.

${ }_{84}$ Kevin McDermott, Communist Czechoslovakia, 1945-89 (London, 2015), 110, points out that in the mid1960s only $11.9 \%$ of 'leading officials' had experienced higher education. Miroslav Vanek and Pavel Mücke, Velvet Revolutions: An Oral History of Czech Society (Oxford, 2016), paint a mixed picture of educational opportunities under Communism, with one informant, Jan Beluš, noting that his relatively high salary as a miner acted as a disincentive for him to gain further qualifications at the Mining Technical School (108).

${ }_{85}$ The phrase Dohnat a predehnat was also used later; for instance, at the 15th Party Congress in 1976.

86 See, for example, Naděžda Kravarová, 'Hlavní rysy vývoje hnutí brigád socialistické práce v Československu', Sociologický Časopis / Czech Sociological Review 19, no. 1 (1983), 132-36.

${ }_{87}$ Filip Pospíšil and Petr Blažek, 'Vrat'te nám vlasy!' (Prague, 2010), 226.

${ }_{88}$ Jan Rychlík, 'Komunistická propaganda v Československu 1945-1989 z hlediska tematického hlediska', in Pažout, Informační boj, 18-27 (26).

${ }_{89}$ The remark does not appear to have been cited in official sources. Husák's word play, which exploited to good effect the rather vulgar and slangy verb 'kráglovat' and the neologism 'krieglovat', was unusually subtle for a Party apparatchik. František Kriegel was an outspoken reform Communist, and the only member of the Central Committee of the KSČ in late August 1968 to refuse to sign the Moscow Protocol, which bound Czechoslovakia to a series of strict Soviet-imposed conditions. He later became a signatory of Charter 77.

${ }_{90}$ For further discussion of this theme, see Paulina Bren, The Greengrocer and his TV (Ithaca and London, 2010), esp. 187-88.

${ }_{91}$ Estimates of the scale of emigration vary widely, but Jaroslav Vaculík, cited in Dušan Drbohlav et al., 'The Czech Republic: On its Way from Emigration to Immigration Country’, 11 May 2009, 11, puts the number from 1968 to 1972 at 127,000 . Available at http://adapt.it/adapt-indice-a-z/wpcontent/uploads/2014/08/idea the czech_republic 2009.pdf.

${ }_{92}$ Miloš Jakeš was General Secretary of the KSČ until November 1989.

93 'Konstitutsiya (Osnovnoi zakon) Soyuza Sovetskikh Sotsialisticheskikh Respublik', http://constitution.garant.ru/history/ussr-rsfsr/1936/

96 Tom Dickins, 'The Linguistic and Rhetorical Legacy of the Prague Spring: Reading the Czechoslovak Communist Party Daily, Rudé právo, from the Late 1980s', Central Europe 14, no. 1 (2016), 26-48 (48). 